\title{
Evaluation of the Molluscicidal Properties of Euphorbia splendens var. hislopii (N.E.B.) Latex: Experimental Test in an Endemic Area in the State of Minas Gerais, Brazil
}

\author{
Nelymar M Mendes/ ${ }^{+}$, Maurício C Vasconcellos ${ }^{*}$, Darcilio F Baptista*, \\ Roberto S Rocha, Virginia T Schall*
}

\author{
Centro de Pesquisas René Rachou-FIOCRUZ, Caixa Postal 1743, 30190-002 Belo Horizonte, MG, Brasil \\ *Departamento de Biologia, Instituto Oswaldo Cruz, Rio de Janeiro, RJ, Brasil
}

Following the positive results obtained regarding the molluscicidal properties of the latex of Euphorbia splendens that were corroborated in laboratory and field tests under restricted conditions, a field study was conducted in experimental streams located in an endemic area. After recording the average annual fluctuations of vectors in three streams, a solution of E. splendens latex at 12 ppm was applied in stream A, a solution of niclosamide at 3 ppm that was applied in stream B and a third stream (C) remained untreated for negative control. Applications of $\mathrm{E}$. splendens and niclosamide resulted in a mortality of $100 \%$ among the snails collected in the streams $A$ and B. No dead snails were found in the negative control stream. A monthly follow-up survey conducted during three consecutive months confirmed the return of vectors to both experimental streams treated with latex and niclosamide. This fact has called for a need to repeat application in order to reach the snails that remained buried in the mud substrate or escaped to the water edge, as well as, newly hatched snails that did not respond to the concentration of these molluscicides. Adults snails collected a month following treatment led us to believe that they had migrate from untreated areas of the streams to those previously treated.

Key words: Euphorbiaceae - Euphorbia splendens - molluscicide plant - Biomphalaria glabrata schistosomiasis

Since the 1930s, researches have investigated the molluscicidal properties of various plants attempting to develop natural substances that could be used by communities (Mozley 1939). The idea was to create a self-sustaining way of producing and using natural molluscicides within an integrated program of control, that is, substances that could supplant unhandy and costly synthetic products (Taylor 1986).

The molluscicidal properties of the different species of Euphorbiaceae have already been studied, using different parts of the plant and extraction processes (Table I). All species, Euphorbia cotinifolia (Pereira et al. 1978), E. pulcherrima (Mendes et al. 1984) and E. tirucalli (Jurberg et al. 1985) have a potential effect on snails of the genus Biomphalaria. However, the latex extracted from E. splendens was found to be effective in a much lower concentration than other parts of the plant or other plants of the same genus previously studied (Table I).

This work was supported by TDR/WHO - ID

${ }^{+}$Corresponding author: Fax: +55-31-295.3115

Received 16 April 1997

Accepted 30 June 1997
E. splendens (Syn E. milii - Zani et al. 1993) is an ornamental plant from Madagascar. It was introduced in Brazil with the purpose of fencing in gardens. It is popularly known as "Coroa de Cristo" (Crown of Thornes), "Coroa de Nossa Senhora" (Our Lady's crown), "Duas amigas" (Two friends), "Colchão de noiva" (Bride's mattress) and "Martírios" (Martyrs) (Pio Corrêa 1984) being one more plant among 360 to be tested for molluscicidal properties in Brazil (Jurberg et al. 1989).

From the phytochemical fractionation of the latex of E. splendens, eight different miliamines were isolated and identified through biological assays performed on adult snails of the genus $B$. glabrata. Three of these miliamines had already been reported in publications, whereas the other five were reported for the first time. The miliamine L. (a dianthraniloyl peptide ester of ingenol) was found to be effective in a dilution of $0,001 \mathrm{ppm}$ (Zani et al. 1993). It is worth recalling that this dilution is roughly 100 times more potent than niclosamide at $0.3 \mathrm{ppm}$ (Martin \& Worthing 1977), a synthetic compound currently used worldwide against the vector of schistosomiasis.

So far toxicological assays made with some miliamines have not shown any carcinogenic properties (Marston \& Hecker 1983). Other tests con- 
TABLE I

Euphorbia species from Brazil presenting molluscicidal activity on Biomphalaria glabrata

\begin{tabular}{lllccc}
\hline Species & Popular name & Tested part & Type extract & Activity ppm & Reference \\
\hline E. cotinifolia L. & Roxinha & Leaves & Hexanic & $<50$ & Pereira et al. 1978 \\
& & Fruits & Pure & $<50$ & \\
& & Stem & Pure & $<50$ & \\
& & Seed's coating & Pure & $<50$ & \\
E. pulcherrima Wild & Bico de & Leaves & Hexanic & Inactive & Mendes et al. 1984 \\
& papagaio & & Ethanolic & Inactive & \\
& & Flowers & Hexanic & Inactive & \\
& & & Ethanolic & Inactive & \\
E. splendens Bojer & Coroa de & Leaves & Hexanic & Inactive & \\
& Cristo & & Ethanolic & 100 & \\
& & Stem & Hexanic & 100 & \\
& & Stem's coating & Hexanic & 100 & \\
& & & Ethanolic & 100 & \\
E. tirucalli L. & & Latex & - & $<0,5$ & Vasconcellos \& Schall 1986 \\
\hline
\end{tabular}

ducted with the latex in natura and/or lyophilized have shown encouraging results such as acute toxicity (Mattos et al. 1989), cutaneous and ocular irritability (Freitas et al. 1991) as well as mutagenicity, cytotoxicity (Schall et al. 1991, Zamith et al. 1996), embroyofeto-toxicity (Souza et al. 1997) and ecotoxicity (Oliveira-Filho \& Paumgartten 1997). Cruz et al. (1996) described a tumor promoter-like activity in vitro. Studies have been carried in vivo to establish the possibility of using latex in field conditions. It was also demonstrated a photodegradation of the molluscicidal latex, which prevents cumulative effects.

Further laboratory tests have confirmed that the latex of E. splendens is seasonably and geographically stable and thus adequate for use in Brazil (Schall et al. 1992).

The field tests conducted in lotic and lentic habitats under restricted conditions have shown a mortality of $100 \%$ for B. glabrata (lentic) and $B$. tenagophila (lotic) using concentrations of $5 \mathrm{ppm}$ and 12 ppm, respectively (Mendes et al. 1992, Baptista et al. 1992).

The purpose of this study is to assess the potential effect of E. splendens in the field and its impact on the natural fluctuation of vector snails through a survey that was conducted during 13 months prior and 3 months after treatment, comparing its effect with that of niclosamide.

\section{MATERIALS AND METHODS}

A field study was conducted in the rural area of Comercinho, a municipality located in Vale do
Jequitinhonha, in the northeast region of the State of Minas Gerais, $713 \mathrm{~km}$ far from the city of Belo Horizonte. It is an hyperendemic area for schistosomiasis, whose prevalence in urban area was of the order of $70 \%$, in 1981, prior to initiating large scale specific treatments. A late survey has shown that the prevalence of the disease had dropped to $13 \%$ (Rocha 1995). Comercinho has 10,000 inhabitants, but only 2,000 of them live in the urban area. The remaining population is distributed in 66 rural communities where sewage systems are inexistent. In the urban area, $87.6 \%$ of the dwellings are connected to waterworks.

The field study was carried out in three experimental streams. They were selected for not posing any risk to the population through contact with the water. Latex was applied in the stream Córrego dos Macacos (A) - Fazenda Alegre and niclosamide in the stream Córrego Água Belas (B) - Fazenda Novo Mundo (Tables II and III). No drug was applied in the stream Córrego da Lage (C) - Fazenda Novo Mundo, selected as a negative control of the streams A and B (Table IV).

Malacological survey was made in the three experimental streams, employing the method of ten scoopfuls at previously select stations and the snails collected were sent to the laboratory to be counted, measured and then, disposed of. From November 1993 to December 1994, prior to any treatment, these streams were surveyed and from January 1995 to March 1995 a follow-up survey was made.

In December 1994, $48 \mathrm{hr}$ after applying the drugs, snails were collected by scoopfuls and 
TABLE II

Monthly fluctuation of Biomphalaria glabrata in the stream Córrego dos Macacos - Fazenda Alegre, where latex of Euphorbia splendens was applied in December 1994

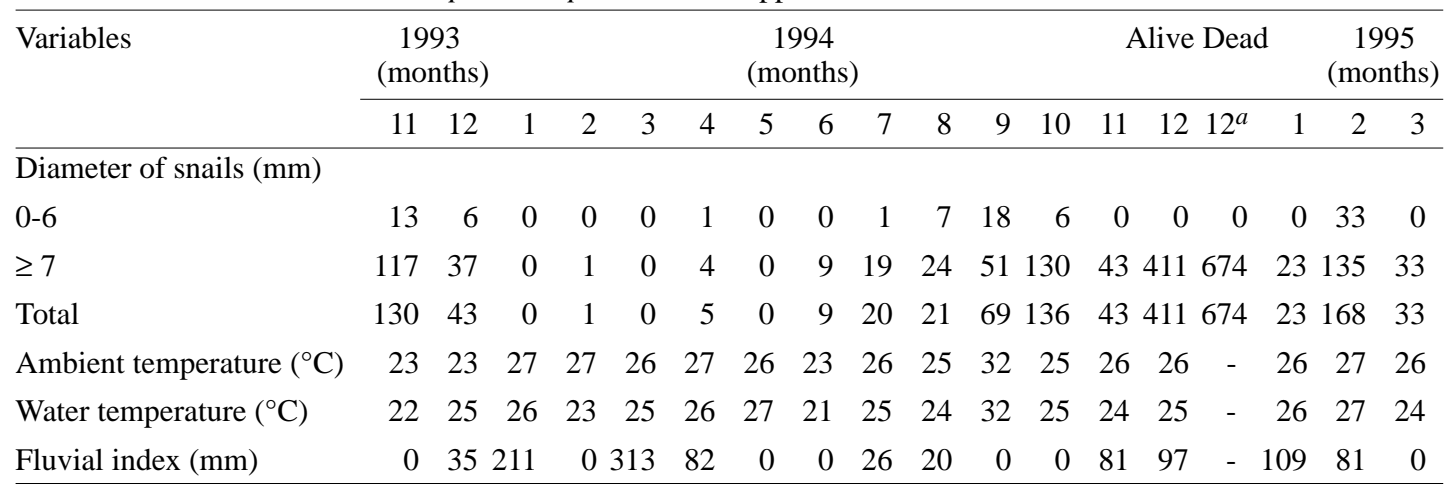

a: number of snails caught $48 \mathrm{hr}$ after treatment.

TABLE III

Monthly fluctuation of Biomphalaria glabrata in the stream Córrego Águas Belas - Fazenda Mundo Novo, where niclosamide was applied in December 1994

\begin{tabular}{|c|c|c|c|c|c|c|c|c|c|c|c|c|c|c|c|c|}
\hline \multirow[t]{2}{*}{ Variables } & \multicolumn{4}{|c|}{$\begin{array}{c}1993 \\
\text { (months) }\end{array}$} & \multicolumn{8}{|c|}{$\begin{array}{c}1994 \\
\text { (months) }\end{array}$} & \multicolumn{2}{|c|}{ Alive Dead } & \multicolumn{2}{|c|}{$\begin{array}{c}1995 \\
\text { (months) }\end{array}$} \\
\hline & 11 & 12 & 1 & 2 & 3 & 4 & 5 & 6 & 7 & 8 & 9 & 10 & 11 & $1212^{a}$ & 2 & 3 \\
\hline \multicolumn{17}{|l|}{ Diameter of snails $(\mathrm{mm})$} \\
\hline $0-6$ & 0 & 7 & 8 & 0 & 0 & 0 & 3 & 0 & 0 & 0 & 0 & 0 & 0 & 0 & 0 & 0 \\
\hline$\geq 7$ & 38 & 22 & 68 & 35 & 0 & 23 & 4 & 28 & 28 & 37 & 133 & 60 & 99 & 268316 & 26131 & 80 \\
\hline Total & 38 & 29 & 76 & 35 & 0 & 23 & 7 & 28 & 28 & 37 & 133 & 60 & 99 & 268316 & 26131 & 80 \\
\hline Ambient temperature $\left({ }^{\circ} \mathrm{C}\right)$ & 24 & 27 & 28 & 29 & 26 & 27 & 34 & 24 & 22 & 23 & 23 & 23 & 23 & $28-$ & $26 \quad 26$ & 27 \\
\hline Water temperature $\left({ }^{\circ} \mathrm{C}\right)$ & 26 & 26 & 26 & 28 & 25 & 27 & 26 & 22 & 22 & 23 & 23 & 23 & 23 & 28 & $25 \quad 25$ & 26 \\
\hline Fluvial index (mm) & 5 & 59 & & & 224 & 80 & 10 & 0 & 8 & 18 & 0 & & 100 & 97 & 90104 & 0 \\
\hline
\end{tabular}

$a$ : number of snails caught $48 \mathrm{hr}$ after treatment.

TABLE IV

Monthly fluctuation of Biomphalaria glabrata in the stream Córrego da Laje - Fazenda Mundo Novo, selected as negative control of the streams where latex and niclosamide were applied

\begin{tabular}{|c|c|c|c|c|c|c|c|c|c|c|c|c|c|c|c|c|c|c|}
\hline \multirow[t]{2}{*}{ Variables } & \multicolumn{3}{|c|}{$\begin{array}{c}1993 \\
\text { (months) }\end{array}$} & \multicolumn{9}{|c|}{$\begin{array}{c}1994 \\
\text { (months) }\end{array}$} & \multicolumn{3}{|c|}{ Alive Alive } & \multicolumn{3}{|c|}{$\begin{array}{c}1995 \\
\text { (months) }\end{array}$} \\
\hline & 11 & 12 & 1 & 2 & 3 & 4 & 5 & 6 & 7 & 8 & 9 & 10 & 11 & 12 & $12^{a}$ & 1 & 2 & 3 \\
\hline \multicolumn{19}{|l|}{ Diameter of snails (mm) } \\
\hline $0-6$ & 2 & 4 & 0 & 0 & 0 & 0 & 0 & 1 & 0 & 2 & 5 & 14 & 7 & 0 & 0 & 6 & 534 & $4 \quad 24$ \\
\hline$\geq 7$ & 89 & 15 & 0 & 4 & 0 & 2 & 0 & 6 & 0 & 4 & 76 & 78 & 49 & 56 & 83 & 71 & 155 & 163 \\
\hline Total & 91 & 19 & 0 & 4 & 0 & 2 & 0 & 7 & 0 & 6 & 81 & 92 & 56 & 56 & 83 & & 7189 & 187 \\
\hline Ambient Temperature $\left({ }^{\circ} \mathrm{C}\right)$ & 26 & 28 & 29 & 28 & 26 & 27 & 35 & 23 & 23 & 24 & 25 & 25 & 24 & 28 & - & 26 & 26 & $5 \quad 27$ \\
\hline Water Temperature $\left({ }^{\circ} \mathrm{C}\right)$ & 24 & 24 & 26 & 29 & 25 & 26 & 26 & 22 & 23 & 23 & 24 & 24 & 23 & 28 & - & 25 & 25 & 525 \\
\hline Fluvial index (mm) & 0 & 592 & & & 224 & 80 & 9 & 0 & 7 & 18 & 0 & & 100 & 97 & - & 90 & 104 & 0 \\
\hline
\end{tabular}

$a$ : number of snails caught $48 \mathrm{~h}$ after treatment. 
caught from sieves placed at different sites of the streams and sent to the laboratory where they were under observation and examined three days after treatment to evaluate their mortality.

The solutions of latex and niclosamide (diluted at $12 \mathrm{ppm}$ and $3 \mathrm{ppm}$, respectively) were applied with a watering can. Safety instructions provided by McCullough (1992), were followed in all stages of the applications in order to prevent any direct contact with the skin and the eyes of the technician. The latex was extracted by stem incision from E. splendens grown in the gardens surrounding the Mineirão Stadium in Belo Horizonte.

\section{RESULTS}

In Tables II to IV, the results of the malacological study carried out from 1993 to 1995 can be observed. A higher density of snails was detected from September to December and a natural decrease in the population occurred from January to June in the stream Córrego dos Macacos (A), from March to May in the stream Córrego Águas Belas (B) and from January to August in the stream Córrego da Laje (C). Ambient temperatures varied from $22^{\circ} \mathrm{C}$ to $35^{\circ} \mathrm{C}$ over the year, averaging $26^{\circ} \mathrm{C}, \mathrm{s}=0.52$ in the stream Córrego dos Macacos, $25.8^{\circ} \mathrm{C}, \mathrm{s}=0.76$ in the stream Córrego Águas Belas and $26.4^{\circ} \mathrm{C}, \mathrm{s}=0.72$ in the stream Córrego da Laje. Water temperature was lower in relation to the ambient temperature. The density of vectors population did not seem to be affected by temperature and rainfalls, which oscillated throughout the months.

As can be seen in Table V, $100 \%$ of mortality were observed after latex and niclosamide application. Although the success of this treatment snails returned to the area a month later. In the stream treated with latex there were an increase in the number of snails in the second month, decreasing in the third month (Table II). In the stream where niclosamide was applied a slight increase in the number of snails during the second month was detected with no modification in the third month (Table III). No snail mortality was reported in the negative control stream (Table IV). Fish mortality was observed only in the stream where niclosamide was applied.

\section{DISCUSSION}

The results confirm the lethal action of latex in lentic environment, whose effect can be compared to that of niclosamide. However, we may infer that both substances are incapable of contributing to erradicate snails. Their defensive behavior such as the burial in the mud substrate and the escape to the water edge contribute to them be unaffected by molluscicidal substances returning soon to the former infestation. In the case of the latex of $E$. splendens, the lethal concentration required to exterminate egg masses is approximately 1,000 times higher than that required for adult snails (Vasconcellos et al. 1986). Newly hatched snails may infest an habitat over a brief lapse of time and one single snail may generate thousands of offsprings, in a period of three months, since they are hermaphrodites and can lay hundreds of eggs.

In this study, besides all facts mentioned above, it is worth noting that the snails collected during the period of three months following application were wider in diameter than the average of two/ three months old specimens. This has led us to believe that the snails migrated or were washed away by heavy rainfalls to the places where latex or niclosamide were applied. These facts call for a need to conduct further tests, which will consist in repeating applications in order to reach newly hatched snails. However, considering that snails may still survive in the mud substrate or at the water edge, environmental measures must be taken into consideration. Since migration is likely to recur including migration against currents, the streams infested will have to undergo extensive treatment, encompassing larger regions than those where people usually has water contact.

TABLE V

Results of the moluscicidal activity of the latex of Euphorbia splendens and niclosamide on Biomphalaria glabrata applied in two streams

\begin{tabular}{|c|c|c|c|c|c|c|c|}
\hline \multirow[b]{2}{*}{ Streams } & \multirow[b]{2}{*}{ Length (m) } & \multirow[b]{2}{*}{ Product } & \multirow[b]{2}{*}{$\begin{array}{l}\text { Dilution } \\
\text { (ppm) }\end{array}$} & \multicolumn{4}{|c|}{ Snails } \\
\hline & & & & $\begin{array}{c}\text { Before } \\
\text { treatment }\end{array}$ & $\begin{array}{c}\operatorname{After}^{a} \\
\text { treatment }\end{array}$ & $\%$ mortality & $\begin{array}{c}\text { Mean } \\
\text { diameter }\end{array}$ \\
\hline Macacos & 200 & Latex & 12 & 411 & 674 & 100 & $8-33$ \\
\hline Águas Belas & 200 & Niclosamide & 3 & 268 & 316 & 100 & $12-35$ \\
\hline Laje & 500 & Control & - & 56 & 83 & 0 & $11-30$ \\
\hline
\end{tabular}

a: snails caught $48 \mathrm{hr}$ after treatment and examined in the laboratory 3 days after treatment. 
Despite the fact that niclosamide can exterminate $100 \%$ of snails, late follow-up surveys have confirmed that vectors will invariably re-infest areas approximately a month following treatment (Pieri et al. 1995). Basing on the areas studied, Pieri has admitted that to maintain a low prevalence of schistosomiasis moluscicide application must be repeated monthly along with treatment of the infected people. According to Pieri, the use of niclosamide as a control strategy would be too costly as well as unfeasible at such intervals. Thus, the use of the latex of E. splendens as an alternative drug has to be assessed and may in turn be implemented in endemic areas for being more convenient to handle and apply. Cost estimates reported by Baptista et al. (1994) indicate that the cultivation, extraction and application of $E$. splendens by communities of endemic areas are feasible. However, it is necessary to conduct experimental studies to assess its use through a variety of approaches in order to confirm such possibilities.

On the other hand, studies will be conducted in areas where water is used by the population only after the conclusion by toxicological tests that the latex of $E$. splendens is free of negative effects.

\section{REFERENCES}

Baptista DF, Vasconcellos MC, Lopes FEF, Silva IP, Schall VT 1992. Evaluation of the molluscidal property of Euphorbia splendens var. hislopii (N.E.B.) (Euphorbiaceae) - 2. Investigation in lotic habitat. Mem Inst Oswaldo Cruz 87: 549-553.

Baptista DF, Vasconcellos MC, Lopes FE, Silva IP, Schall VT 1994. Perspectives of using Euphorbia splendens as a molluscicide in schistosomiasis control programs. Southeast Asian J Trop Med Public Health 25: 419-424.

Cruz CM, Kasper P, Cataldo A, Zamith H, Paumgartten FJR 1996. Tumor promoter like activity of the molluscicidal latex of "Crown-of-Thorns" (Euphorbia milli var. hislopii) in the V79 metabolic cooperation assay. Braz J Med Biol Res 29: 1519-1523.

Freitas JCBR, Presgrave OAF, Fingola FF, Menezes MAC, Vasconcellos MC, Schall VT, Paumgartten FJR 1991. Toxicological study of the molluscicidal latex of Euphorbia splendens. Irritant action on skin and eye. Mem Inst Oswaldo Cruz 86: 87-88.

Jurberg P, Cabral Neto JB, Schall VT 1985. Moluscicide activity of the "avelos" plant (Euphorbia tirucalli,L.) on Biomphalaria glabrata, the molusc vector of schistosomiasis. Mem Inst Oswaldo Cruz 80: 423427.

Jurberg P, Vasconcellos MC, Mendes NM 1989. Plantas empregadas como moluscicidas: Uma visão crítica. Mem Inst Oswaldo Cruz 84: 76-83.

McCullough FS 1992. The role of mollusciciding in schistosomiasis control. WHO/Schist/92.107.

Marston A, Hecker E 1983. On the active principle of Euphobiacea VI. Planta Med 47: 141-147.

Martin H, Worthing CR 1977. Pesticide manual - basic information on the chemical used as active components of pesticides. British Crop Protection Council, $383 \mathrm{pp}$.

Mattos RC, Vasconcellos MC, Lopes MC, Souza CAM, Alves EN, Farias M, Schall VT, Paumgartten FJR 1989. Estudo toxicológico do látex moluscicida da "coroa de cristo" (Euphorbia splendens var hislopii). I. Ensaios preliminares. IV Reunião Anual da Federação da Sociedade de Biologia Experimental, 4, Caxambu, MG, 320 pp.

Mendes NM, Baptista DF, Vasconcellos MC, Schall VT 1992. Evaluation of the molluscicidal properties of Euphorbia splendens var. hislopii (N.E.B) (Euphorbiaceae). 1.Experimental test in lentic habitat. Mem Inst Oswaldo Cruz 87: 21-23.

Mendes NM, Pereira JP, Souza CP, Azevedo MLLP 1984. Ensaios preliminares em labotatório para verificar a ação moluscicida de algumas espécies da flora brasileira. Rev Saúde Públ São Paulo 18: 348354.

Mozley A 1939. Freshwater mollusca of the Tanganyika Territory and the Zanzibar Protectorate, and their relation to human schistosomiasis. Trans $R$ Soc Edinburgh 59: 687-730.

Oliveira-Filho EC, Paumgartten FJR 1997. Photodegradation of the molluscicidal latex of Crown-ofThorns (Euphorbia milli var. hislopii). Mem Inst Oswaldo Cruz. 92: 657-659 .

Pereira JP, Souza CP, Mendes NM 1978. Propriedades moluscicidas da Euphorbia cotinifolia. Rev Bras Pesq Méd Biol 11: 345-351.

Pieri O, Gonçalves JF, Sarquis O 1995. Repeated focal mollusciciding for snail control in sugar-cane area of northeast Brazil. Mem Inst Oswaldo Cruz 90: 535536.

Pio Correa M 1984. Dicionário de plantas úteis do Brasil e das exóticas cultivadas. Imprensa Nacional, Ministério da Agricultura. Instituto Brasileiro de Desenvolvimento Florestal, Rio de Janeiro, 533 pp.

Rocha RS 1995. A 18-year prospective study on morbidity due to Schistosoma mansoni in a highly endemic area in the State of Minas Gerais, Brazil. Resumo 5. Simpósio Internacional de Esquistossomose, Salvador, Bahia.

Schall VT, Vasconcellos MC, Valent GU, Sato MIZ, Furlan EV, Sanchez PS 1991. Evaluation of the genotoxic activity and acute toxicity of Euphorbia splendens latex, a molluscicide for the control of schistosomiasis. Braz J Med Biol Res 24: 573-582.

Schall VT, Vasconcellos MC, Villaça-Coelho AL, Ferreira-Lopes FE, Silva IP 1992. Evaluation of temporal, seasonal and geographic stability of the molluscicidal property of Euphorbia splendens latex. Rev Inst Med Trop São Paulo 34: 183-191.

Souza CAM, De-Carvalho RR, Kuriyma SN, Araújo IB, Rodrigues RP, Vollmer RS, Alves EN, Paumgartten FJR 1997. Study of the embryofeto-toxicity of Crown-of-Thorns (Euphorbia milli var. hislopii) latex, a natural molluscicide. Braz J Med Bio Res (in press)

Taylor P 1986. Water supply and sanitation programmes to support schistosomiasis control in Zimbabwe. Trop 
724 Euphorbia splendens Test in Endemic Area - NM Mendes et al.

Med Parasit 37:188.

Vasconcellos MC, Schall VT 1986. Latex of "Coroa de Cristo "(Euphorbia splendens): An effective molluscicide. Mem Inst Oswaldo Cruz 81: 475-476.

Zamith HPS, Paumgartten FJR, Speit G 1996. Evaluation of the mutagenicity of the moluscicidal latex of
Christ's Crown (Euphorbia milii var hislopii) in mammalian cells in vitro and in vivo. Mutagenic Res 368: $15-20$.

Zani CL, Marston A, Hamburger M, Hostettmann K 1993. Moluscicidal milliamines from Eupphorbia milii var. hislopii. Phytochemistry 34: 89-95. 